Pediat. Res. 4: 76-81 (1970)

Infants premature infants maternal blood progesterone placental transfer

\title{
Concentrations of Progesterone in the Plasma of Mothers and Infants at Time of Birth
}

\author{
P.W. Gonly, T.Morrison, D. H.Sandberg and W.W. Gleveland ${ }^{[23]}$ \\ Department of Pediatrics, University of Miami School of Medicine, Miami, Florida, USA
}

Extract

A highly sensitive method utilizing competitive protein binding was used to study concentrations of progesterone in the plasma of mothers, in umbilical cord plasma, and in the plasma of full-term and premature infants in the immediate postpartum period.

Blood samples were obtained from 20 mothers during labor and from the cords of their infants at delivery. Most of these infants were also studied at 2 or 3 days of age. For purposes of comparison, a second series of samples was obtained from control subjects using needle aspiration to obtain samples from the umbilicus; 14 samples were studied.

In the mothers, concentrations of progesterone in plasma ranged from 46 to $387 \mathrm{ng} / \mathrm{ml}$ (mean: $129 \pm 78 \mathrm{sD}$ ); in cord blood, progesterone levels ranged from 440 to $2,000 \mathrm{ng} / \mathrm{ml}$ (mean: $1,030 \pm 412$ $\mathrm{SD}$ ); and in blood from the umbilical vein, concentrations of progesterone ranged from 310 to 720 $\mathrm{ng} / \mathrm{ml}$ (mean: $562 \pm 140 \mathrm{sD}$ ).

A total of 27 full-term newborns was studied at 24,48 , and $72 \mathrm{~h}$ of life. In four cases, blood was obtained from the same infant at 12, 24, and $72 \mathrm{~h}$ of life. The highest concentrations of progesterone were noted during the first $24 \mathrm{~h}$ of life, with levels ranging from 13 to $32 \mathrm{ng} / \mathrm{ml}$ (mean: $19 \mathrm{ng} / \mathrm{ml}$ ) at $12 \mathrm{~h}$, and from 2 to $32 \mathrm{ng} / \mathrm{ml}$ (mean: $16 \mathrm{ng} / \mathrm{ml}$ ) at $24 \mathrm{~h}$. By day 2, levels of progesterone had decreased to $3-20 \mathrm{ng} / \mathrm{ml}$ (mean: $10 \mathrm{ng} / \mathrm{ml}$ ) and by day 3 were reduced to $0-16 \mathrm{ng} / \mathrm{ml}$ (mean: $8 \mathrm{ng} / \mathrm{ml}$ ).

Thirty-two premature infants, with birth weights of from 1,317 to 2,465 $\mathrm{g}$, and ranging in gestational age from 30 to 40 weeks, were also studied. In several cases serial blood samples were obtained by the same methods used with the full-term infants. Two sets of twins were included. In premature infants, as with full-term newborns, a range of $4-34 \mathrm{ng} / \mathrm{ml}$ (mean: $14 \mathrm{ng} / \mathrm{ml}$ ) was found at $12 \mathrm{~h}$ of life, decreasing rapidly to $2-6 \mathrm{ng} / \mathrm{ml}$ (mean: $3 \mathrm{ng} / \mathrm{ml}$ ) by $24 \mathrm{~h}$ of life. These low concentrations persisted throughout days 2 and 3.

There was no significant difference between concentrations of progesterone in plasma in full-term and premature infants at 2-3 days of age. It appeared that premature infants were as able to clear progesterone from the plasma as were the full-term infants.

\section{Speculation}

The data obtained in this study support the concept that large amounts of progesterone are delivered from the placenta to the fetus. This compound may be a precursor of G-21 steroids such as cortisol, synthesized by the fetal adrenal. Progesterone has also been shown to effect respiration in animals 
and man $[7,8,14,15]$ and an effect on neonatal respiratory mechanisms and disease may occur, although this has not been demonstrated.

Maternal blood has a relatively large concentration of progesterone which diminishes rapidly following delivery of the placenta. Presumably the compound exerts some effect in the maintenance of pregnancy. Its exact role has not been established.

\section{Introduction}

Reports confirm that there is a marked increase in the concentration of progesterone and its metabolites in maternal blood and urine during pregnancy $[12,13$, $19,21]$. There is a rapid decline following delivery of the infant and placenta [12, 13,21]. Previous studies have included determination of progesterone concentration in maternal and cord blood, but only two studies are available $[6,10]$ regarding concentrations of progesterone in the blood of the neonate. Because methods used previously required large amounts of blood, study of young infants was not practical; now, however, the competitive protein-binding assay, described by Murphy [16] and modified by NeILl et al. [17], is sufficiently sensitive so that measurements can be made with very small samples of blood. This technique [17] has been used in this investigation to measure concentrations of progesterone in blood from mothers, cords, and infants at delivery, and in mothers and babies during the immediate postpartum period. Data from studies of infants delivered prematurely were also compared with those obtained from babies delivered at term.

\section{Materials and Methods}

Group 1 consisted of 20 mothers at time of delivery of term pregnancy. Peripheral venous blood was obtained from these mothers on the delivery table during active. labor. Immediately upon delivery of the placenta, blood was milked from the cord. Then, at 2-3 days postpartum, blood was again obtained from the mothers and infants. Blood was heparinized and the plasma was separated and frozen within $1 \mathrm{~h}$. Blood obtained from the umbilical vein by needle aspiration was studied in a different series of 14 cases for comparison with cord blood.

Group 2 consisted of 27 full-term newborns, some of which were born to mothers in group 1 . These infants were normal and the deliveries were uncomplicated. Blood was obtained between $12-24 \mathrm{~h}$ of life in 10 instances, $24-48 \mathrm{~h}$ in 12 instances, and up to $72 \mathrm{~h}$ of life in 13 instances. In four instances, blood was obtained from the same infant at $12,24,48$, and $72 \mathrm{~h}$ of life.
Group 3 consisted of 32 premature infants ranging in birth weight from 1,317 to $2,465 \mathrm{~g}$; it included two sets of twins. Length of gestation varied from 30 to 40 weeks. Blood was obtained from these infants at approximately $12,24,48$, and $72 \mathrm{~h}$ of life. In three cases, serial blood samples were obtained.

The method used to determine concentrations of progesterone in plasma has been described in detail [17] and is based on the competitive binding of progesterone and corticosterone on the corticosteroidbinding globulin (CBG) of dog plasma. Extraction of $0.1-0.5 \mathrm{ml}$ of plasma is performed and the extract is subjected to thin-layer chromatography (TLG). Markers appearing above and below the progesterone spot are used to locate the progesterone more accurately. Isatin, a yellow dye which has an $R_{F}$ value identical to $17 \alpha$-hydroxyprogesterone and thus moves behind progesterone in our solvent system, is used as one marker. The other marker is an unknown substance in petroleum ether that fluoresces blue-white and that moves ahead of progesterone. During extraction, losses vary from 10 to $25 \%$ depending upon the purity of the petroleum ether used. The remaining loss occurs in the TLC sequence. Radioactive progesterone, added to pooled male plasma, has an average final recovery rate of $50 \%$, and the results reported below have been corrected for this loss.

One milliliter of diluted male dog plasma, to which tritiated corticosterone was added, was pipetted into tubes containing dried eluates obtained from TLG. Tubes were then placed in a water bath, $45^{\circ}$ for $5 \mathrm{~min}$, mixed, and transferred to an ice bath for $10 \mathrm{~min}$. Eighty milligrams of Florisil were added to each tube and the solution was mixed for $30 \mathrm{sec}$; an aliquot of the supernatant was removed and counted. A standard curve was prepared in duplicate using 1, 2, 5, and 10 ng of progesterone. The amount of progesterone in each sample was determined by comparing the values with a standard curve established with each assay. These values were corrected for procedural losses and dilution factors. The recovery of a given amount of progesterone added to pooled male plasma provided a control on substances that might interfere in the protein-binding assay; this control was processed with each assay.

The use of petroleum ether as an extraction medium confers some degree of specificity to this method be- 
cause the cortisol and similar steroids abundant in plasma during pregnancy are removed even before the TLC step. Progesterone was separated from remaining compounds by TLC, using markers that moved on either side as well as in front of and behind the progesterone spot. Analysis of competitive protein binding shows a degree of specificity for individual steroids [16]. Results obtained with the competitive protein-binding method have compared favorably [9] with results obtained using a double isotope derivative method. The double isotope-derivative method for this comparison was a modification of that described by Woolever and Goldfein [20]. The correlation coefficient between the results of the two methods was 0.83 .

\section{Results}

In group 1 (table I), the peripheral venous plasma obtained from the mothers at the time of delivery contained a mean concentration of $129 \mathrm{ng} / \mathrm{ml}$ of progesterone (range: $46-387 \mathrm{ng} / \mathrm{ml}$; sD: $\pm 78 \mathrm{ng} / \mathrm{ml}$ ). Umbilical vein blood obtained by needle aspiration contained a mean concentration of progesterone of 562 $\mathrm{ng} / \mathrm{ml}$ (range : $310-720 \mathrm{ng} / \mathrm{ml}$; $\mathrm{sD}: \pm 140 \mathrm{ng} / \mathrm{ml}$ ). Cord plasma had greater concentrations of progesterone (mean: $1,030 \mathrm{ng} / \mathrm{ml}$; range: $440-2,000 \mathrm{ng} / \mathrm{ml}$; SD: $\pm 412 \mathrm{ng} / \mathrm{ml}$ ). By day 2 or 3 postpartum, levels of progesterone in maternal plasma had dropped to a mean of $8 \mathrm{ng} / \mathrm{ml}$ (range: $1-24 \mathrm{ng} / \mathrm{ml}$; sD : $\pm 6 \mathrm{ng} / \mathrm{ml}$ ). Similar concentrations of progesterone were found in the plasma of the infants (mean: $9 \mathrm{ng} / \mathrm{ml}$; range: $0-17$ $\mathrm{ng} / \mathrm{ml} ; \mathrm{sD}: \pm 4 \mathrm{ng} / \mathrm{ml})$.

In group 2 (table II), which consisted of 27 full-term newborns, the highest concentrations of progesterone in plasma were noted during the first $24 \mathrm{~h}$ of life. After this time, most of the infants had cleared the plasma of significant amounts of progesterone. In five cases studied at $12 \mathrm{~h}$ of life, concentration levels ranged from 13 to $32 \mathrm{ng} / \mathrm{ml}$ (mean: $19 \mathrm{ng} / \mathrm{ml}$ ). At $24 \mathrm{~h}$, the range was 2-32 $\mathrm{ng} / \mathrm{ml}$ (mean: $16 \mathrm{ng} / \mathrm{ml}$ ). By day 2 of life, progesterone concentrations in plasma decreased to 3-20 ng/ml (mean: $10 \mathrm{ng} / \mathrm{ml}$ ), and by day 3 postpartum, 0-16 ng/ml (mean: $8 \mathrm{ng} / \mathrm{ml}$ ) were observed.

Group 3 consisted of 32 premature infants (table III). Here also the highest concentrations of progesterone were found during day 1 of life. A range of $4-34 \mathrm{ng} / \mathrm{ml}$ at $12 \mathrm{~h}$ of life (mean: $14 \mathrm{ng} / \mathrm{ml}$ ) decreased rapidly to $2-6 \mathrm{ng} / \mathrm{ml}$ (mean: $3 \mathrm{ng} / \mathrm{ml}$ ) by $24 \mathrm{~h}$. These low levels persisted throughout days 2 and 3 postpartum.

We were unable to subject the data on newborns and prematures to statistical analysis since the exact time intervals were not known for each individual studied. Group comparison revealed no significant difference between newborn and premature infants for the method used.

\section{Discussion}

It has been shown by LURIE et al. [13], using gas-liquid chromatography (GLC), that there is a steady increase in concentrations of progesterone in blood as pregnancy progresses. They reported a slight decrease before the onset of, and again during, active labor. In one case, LURIE et al. observed that a marked decrease in pro-

Table I. Full-term pregnancies ${ }^{1}$

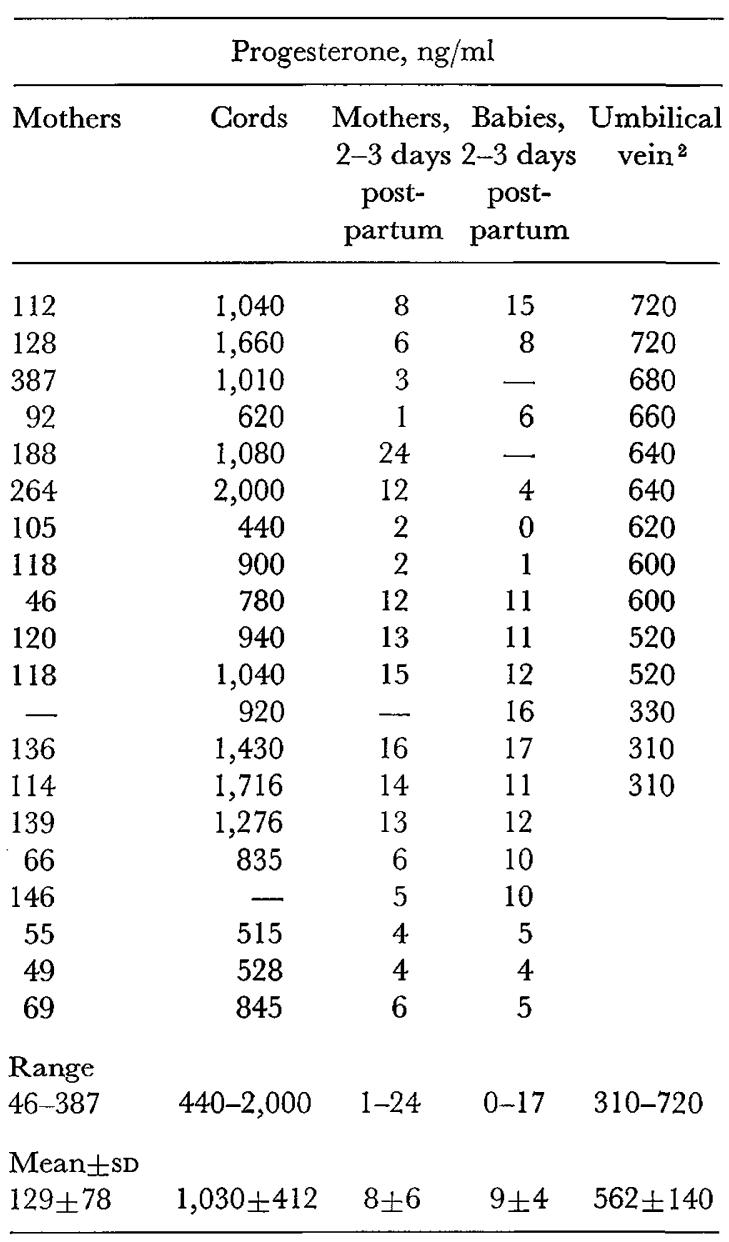

1 Concentrations of progesterone in plasma in mothers, in cords at time of delivery, and in mothers and infants 2-3 days postpartum.

${ }^{2}$ The umbilical vein samples were obtained from another series of cases. 
gesterone levels occurred within $10 \mathrm{~min}$ after delivery of the placenta. YANNONE et al. [21] have recently reported similar results although they did not note a decrease before the onset of labor. Llauro et al. [12] have recently studied, in serial fashion, several women from 34 weeks gestation to onset of labor and after delivery; they report similar findings. Our data (table I) for progesterone in maternal plasma from peripheral veins agree reasonably well with those of LLAURo et al. [12] who found concentrations of $20.7 \pm 7.3 \mu \mathrm{g} / 100 \mathrm{ml}$ at the onset of labor, and with HARBERT et al. [10] who

Table II. Concentrations of progesterone in plasma in full-term newborn infants from 1-3 days of age

\begin{tabular}{|c|c|c|c|c|}
\hline \multirow[b]{2}{*}{ Infant no. } & \multicolumn{4}{|c|}{$\begin{array}{l}\text { Progesterone conc in plasma, } \\
\qquad \mathrm{ng} / \mathrm{ml}\end{array}$} \\
\hline & $0-12 \mathrm{~h}$ & $12-24 \mathrm{~h}$ & $24-48 \mathrm{~h}$ & $48-72 \mathrm{~h}$ \\
\hline 1 & & & 9 & \\
\hline 2 & & & 20 & \\
\hline 3 & & 30 & & \\
\hline 4 & & 32 & & \\
\hline 5 & & & 17 & \\
\hline 6 & & & 3 & \\
\hline 7 & & & & 1 \\
\hline 8 & & & 15 & \\
\hline 9 & & & 8 & \\
\hline 10 & & 4 & & \\
\hline 11 & & 6 & & \\
\hline 12 & & 16 & & \\
\hline 13 & & & & 2 \\
\hline 14 & & & & 0 \\
\hline 15 & & & & 1 \\
\hline 16 & & & & 11 \\
\hline 17 & & & & 11 \\
\hline 18 & & & & 12 \\
\hline 19 & & & & 16 \\
\hline 20 & & & 17 & \\
\hline 21 & & & 11 & \\
\hline 22 & & & & 12 \\
\hline 23 & $32^{1}$ & 14 & 5 & 10 \\
\hline 24 & $13^{1}$ & 2 & 11 & 10 \\
\hline 25 & $13^{1}$ & 8 & 3 & 5 \\
\hline 26 & $15^{1}$ & 9 & 3 & 4 \\
\hline 27 & 20 & 16 & & \\
\hline Range & $13-32$ & $2-32$ & $3-20$ & $0-16$ \\
\hline Mean & 19 & 16 & 10 & 8 \\
\hline
\end{tabular}

1 Blood was obtained from this infant at $12,24,48$, and $72 \mathrm{~h}$ of life. found progesterone levels of $15.4 \mu \mathrm{g} / 100 \mathrm{ml}$ in the maternal vein. In this study, concentrations of progesterone in plasma from the umbilical vein were between the mean of $72.4 \mu \mathrm{g} / 100 \mathrm{ml}$ found by HARBERT et al. [10] and $37.2 \mu \mathrm{g} / 100 \mathrm{ml}$ found by ZANDER [22]. The discrepancy between the values in blood drained from the cord and in blood aspirated from the um-

Table III. Concentrations of progesterone in plasma in premature infants from 1-3 days of age

\begin{tabular}{|c|c|c|c|c|c|}
\hline \multirow[t]{2}{*}{$\begin{array}{l}\text { Gesta- } \\
\text { tion, wk }\end{array}$} & \multirow[t]{2}{*}{$\begin{array}{l}\text { Birth wt, } \\
\mathrm{g}\end{array}$} & \multicolumn{4}{|c|}{$\begin{array}{c}\text { Progesterone conc in plasma, } \\
\text { ng/ml }\end{array}$} \\
\hline & & $0-12 \mathrm{~h}$ & $24 \mathrm{~h}$ & $48 \mathrm{~h}$ & $72 \mathrm{~h}$ \\
\hline 40 & 2,465 & & 2 & & \\
\hline 36 & 2,438 & & & 1 & \\
\hline 40 & 2,438 & & & & 2 \\
\hline 39 & 2,352 & & & 3 & \\
\hline 38 & 2,297 & & 2 & & \\
\hline 38 & 2,297 & & 5 & & \\
\hline 36 & 2,270 & & & & 2 \\
\hline \multirow[t]{2}{*}{36} & 2,252 & 8 & & & \\
\hline & 2,247 & & 5 & & \\
\hline 30 & 2,238 & & & 2 & \\
\hline 40 & 2,225 & & 2 & & \\
\hline 36 & 2,211 & 27 & & & \\
\hline 40 & 2,175 & & & & 4 \\
\hline 32 & 2,175 & & & & 3 \\
\hline 40 & 2,156 & & 2 & & \\
\hline $37^{1}$ & 2,125 & 8 & 4 & & \\
\hline 30 & 2,120 & 6 & & & \\
\hline 35 & 2,106 & & & 2 & \\
\hline \multirow[t]{2}{*}{36} & 2,097 & 10 & & & \\
\hline & 2,070 & & & 4 & \\
\hline 40 & 2,043 & 16 & & & \\
\hline 35 & 1,975 & & 6 & & \\
\hline $35^{1}$ & 1,943 & 4 & 2 & 2 & \\
\hline \multirow[t]{2}{*}{40} & 1,930 & 34 & & & \\
\hline & 1,930 & & 2 & & \\
\hline $32-34^{1}$ & 1,930 & 5 & 2 & 4 & \\
\hline 30 & 1,898 & & 4 & & \\
\hline \multirow[t]{2}{*}{40} & 1,884 & & & & 2 \\
\hline & 1,702 & & 2 & & \\
\hline \multirow[t]{3}{*}{40} & 1,607 & 27 & & & \\
\hline & 1,416 & & & 5 & \\
\hline & 1,317 & & & 3 & \\
\hline Range & & $4-34$ & $2-6$ & $1-5$ & $2-4$ \\
\hline Mean & & 14 & 3 & 3 & 2 \\
\hline
\end{tabular}

${ }^{1}$ Blood was obtained serially in these infants. 
bilical vein is unexplained. LuRIE et al. [13] found a progesterone concentration of $71.0 \mu \mathrm{g} / 100 \mathrm{ml}$ in the intervillous pool compared with $61.5 \mu \mathrm{g} / 100 \mathrm{ml}$ in the umbilical vein.

It has been known for some time that progesterone is produced by the human placenta in large amounts [19]. The reason for production of such concentrations of progesterone as pregnancy progresses to term has not been determined. Studies [4] performed during the late first and midtrimester (10-27 weeks of gestation) of pregnancy, in cases of threatened abortion, revealed no definite correlation with progesterone levels in plasma. Some patients aborted despite normal levels. Other studies $[1,21]$ have shown that progesterone concentration in plasma does not decrease prior to onset of labor. In cases of induced abortion [2], pregnanediol excretion in the urine decreased after the umbilical cord was severed, but while the placenta remained in situ a constant level of excretion was maintained.

There have been two studies of progesterone concentration in the plasma of newborn infants; one [6], using a bioassay method for progestins, revealed no detectable amounts in the plasma or serum of the newborn after $45 \mathrm{~h}$ postpartum; the second study [10] revealed that progesterone was detectable in $50 \%$ of the neonates studied at 12 or $24 \mathrm{~h}$ postpartum. To date, there have been no reports of progesterone in plasma in premature infants. A study of placental tissues of spontaneous abortions and premature births [11] showed that levels of progesterone in these tissues were less than in the placentas of normal pregnancies.

The major urinary metabolite of progesterone in the mother is pregnanediol. Urinary metabolites of progesterone have been studied during the newborn period utilizing GLC techniques [5, 19]. Ramos et al. [18] revealed that pregnanediol glucuronide was present until day 5 of life, after which it was not detectable in most infants. These results are consistent with the changes in progesterone concentrations in plasma found in our study of full-term newborns during the first few days of life.

Conflicting reports of excretion of pregnanediol in the urine in premature births have been published. It is known that newborns do not convert progesterone into pregnanediol as effectively as adults [3], therefore, studies of metabolites in the urine often are not as satisfactory a method for investigating steroid metabolism as is measurement of plasma concentrations of the hormone. For this reason, we have attempted to establish the range of normal progesterone concentrations in the plasma of full-term and premature infants of varying birth weights and gestational ages. There appears to be no significant difference between premature and full-term newborns at 2-3 days of age.
From our results (tables II and III), it would appear that premature infants are able to clear the body of progesterone as well as the full-term infants studied here.

\section{Summary}

Twenty full-term births were studied to determine the range of normal levels of progesterone in plasma in peripheral venous blood of mothers at delivery, in cord blood, and in plasma of mothers and babies at 2-3 days postpartum.

Twenty-seven full-term newborns were studied at 1-3 days of age and the progesterone levels reported in the plasma were compared with the progesterone levels found in the plasma of 32 premature infants during the first 3 days of life. No significant difference was noted between these two groups. The premature infants were able to clear the plasma of progesterone as well as the term infants.

\section{References and Notes}

1. Artken, E.H.; Preedy, J.R.K.; Eton, B. and SHORT, R.V.: Oestrogen and progesterone levels in foetal and maternal plasma at parturition. Lancet ii: 1096 (1958).

2. Cassmer, O.: Hormone production of the isolated human placenta. Acta endocrin., Kbh. Suppl. 45: 40-58 (1959).

3. Drczfalusy, E.: Metabolism of sex hormones by the foetus; in: H.M. GAREY: Modern trends in human reproductive physiology, 1st series (Butterworth, London 1963).

4. Eton, B. and ShorT, R.V.: Blood progesterone levels in abnormal pregnancies. J. Obstet. Gynec. brit. Gwlth. 67: 785 (1960).

5. Ferris, B. and Green, O. C.: Pregnanediol excretion by newly born infants. Amer.J. Dis. Child. 115: 693 (1968).

6. Forbes, T.R.; Leobow, S.G.; Ray, E.W. and GardNer, L. I.: Progestin in the blood of newborn infants. J. clin. Endocrin. Metab. 21: 862 (1961).

7. Goodland, R.L.; Reynolds, J.G.; MaCoard, A.B. and Pommerenke, W.T.: Respiratory and electrolyte effects induced by estrogen and progesterone. Fertil. Steril. 4: 300 (1953).

8. Goodland, R.L.; Reynolds, J.G. and PommeRENKE, W.T.: Alveolar carbon dioxide tension levels during pregnancy and early puerperium. J. clin. Endocrin. Metab. 14: 522 (1954).

9. Hagerman, D.D. and Williams, K. L.: Comparison of a protein binding displacement method with a double isotope derivative method for deter- 
mination of plasma progesterone. Amer.J. Obstet. Gynec. 104: 114 (1969).

10. Harbert, G.M.; McGaughey, H.S., Jr.; ScogGIN, W.A. and Thorton, W.N.: Concentration of progesterone in newborn and maternal circulations at delivery. Obstet. Gynec., N.Y. 23: 413 (1964).

11. Kumar, D.; Azoury, R.S. and Barnes, A.C.: Studies on human premature births. I. Placental progesterone concentrations. Amer.J. Obstet. Gynec. 87: 126 (1963).

12. Llauro, J.L.; Runnebaum, B. and Zander, J.: Progesterone in human peripheral blood before, during and after labor. Amer.J. Obstet. Gynec. 101: 867 (1968).

13. Lurie, A. O.; Reid, D.E. and Villee, C.A.: The role of the fetus and placenta in maintenance of plasma progesterone. Amer.J. Obstet. Gynec. 96. 670 (1966).

14. Lyons, H.A. and Antonio, R.: The sensitivity of the respiratory center in pregnancy and after the administration of progesterone. Trans. Ass. amer. Phys. 72: 173 (1959).

15. Lyons, H.A. and Huang, C.T.: Therapeutic use of progesterone in alveolar hypoventilation associated with obesity. Amer.J. Med. 44: 881 (1968).

16. Murphy, B.E.P.: Application of the property of protein-binding to the assay of minute quantities of hormones and other substances. Nature, Lond. 201: 679 (1964).

17. Neill, J.D.; Johansson, E.D.B.; Datta, J.K. and KNOBIL, E.: The relationship between the plasma levels of luteinizing hormone and progesterone during the normal menstrual cycle. J. clin. Endocrin. Metab. 27: 1167 (1967).

18. Ramos, A.; Silverberg, M. and Stern, L. : Pregnanediols and neonatal hyperbilirubinemia. Amer. J. Dis. Child. 111: 353 (1966).

19. VenNing, E. H.: Further studies on the estimation of small amounts of sodium pregnanediol glucuronidate in urine. J. biol. Chem. 126: 595 (1938).

20. Woolever, C.A. and Goldfein, A.: A doubleisotope derivative method for plasma progesterone assay. Int.J.appl. Radiat. 14: 163 (1963).

21. Yannone, M.E.; MaCurdy, J.R. and Goldfein, A.: Plasma progesterone levels in normal pregnancy, labor and the puerperium. II. Clinical data. Amer.J. Obstet. Gynec. 101: 1058 (1968).

22. ZANDER, J. : Die Hormonbildung der Placenta und ihre Bedeutung für die Frucht. Arch. Gynäk. 198: 113 (1964).

23. Requests for reprints should be addressed to: William W. Gleveland, M.D., University of Miami School of Medicine, P.O.Box 875, Miami, FL 33152 (USA).

24. Accepted for publication August 21, 1969. 